\title{
Water quality and zooplankton in tanks with larvae of Brycon Orbignyanus (Valenciennes, 1949)
}

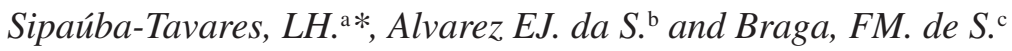 \\ áLaboratório de Limnologia e Produção de Plâncton, Centro de Aqüicultura, Universidade Estadual Paulista - UNESP, \\ Via de Acesso Prof. Paulo D. Castellane, s/n, CEP 14884-900, Jaboticabal, SP, Brazil

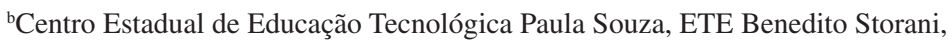 \\ Av. Antônio Pincinato, 4355, CEP 13211-771, Jundiaí, SP, Brazil \\ 'Departamento de Zoologia, Instituto de Biociências, Universidade Estadual Paulista - UNESP, \\ Av. 24a, 1515, CEP 13506-900, Rio Claro, SP, Brazil \\ *e-mail: sipauba@ caunesp.unesp.br \\ Received March 27, 2006 - Accepted September 27, 2006 - Distributed February 29, 2008
}

(With 5 figures)

\begin{abstract}
Due to the importance of water variables conditions and available food in the development and survival of fish larvae, the current research evaluates the effects of two different food treatments (ration + zooplankton and only zooplankton) and water quality in tanks with Brycon orbignyanus larvae. Total water transparency (45 cm) has been mainly associated with short residence time, continuous water flow and shallowness. Dissolved oxygen ranged between 1.32 and $7.00 \mathrm{mg} . \mathrm{L}^{-1}$ in tanks with ration + zooplankton and between 1.82 and $7.60 \mathrm{mg} . \mathrm{L}^{-1}$ in tanks with only zooplankton treatments. Nutrients were directly affected by the addition of ration in water, with the exception of nitrite. Ten Rotifera species were found represented by high densities, ranging between $8.7 \times 10^{5}$ and $1.3 \times 10^{6}$ org. $\mathrm{m}^{-3}$, throughout the experimental period (January to March/1996). Cladocera had the lowest density in the four tanks under analysis and ranged between $4.7 \times 10^{4}$ and $2.1 \times 10^{5}$ org. $\mathrm{m}^{-3}$ for the six species. Diaphanosoma birgei has been classified as the most frequent species. Since ration + zooplankton produced better larvae yield, this treatment is recommended for Brycon orbignyanus larvae.
\end{abstract}

Keywords: Brycon orbignyanus, larvae tanks, limnology, zooplankton.

\section{Qualidade da água e zooplâncton em tanques de larvicultura de Brycon orbignyanus (Valenciennes, 1949)}

\begin{abstract}
Resumo
Devido à importância das condições das variáveis da água e do alimento disponível no desenvolvimento e sobrevivência das larvas de peixes, o objetivo deste estudo foi avaliar o efeito do uso de dois tratamentos alimentares (ração + zooplâncton e somente zooplâncton) e a qualidade da água, em tanques de larvicultura de Brycon orbignyanus. A transparência total da água $(45 \mathrm{~cm})$ esteve associada principalmente ao curto tempo de residência, fluxo contínuo e baixa profundidade. As concentrações de oxigênio dissolvido variaram de 1,32 a 7,00 mg. $\mathrm{L}^{-1}$ no tratamento contendo ração + zooplâncton, e de 1,82 a 7,60 mg. $\mathrm{L}^{-1}$ no tratamento contendo somente zooplâncton. Os nutrientes foram diretamente influenciados pela adição de ração no meio com exceção do nitrito. Rotifera apresentou a maior densidade, variando ao longo do período experimental de $8,7 \times 10^{5}$ a 1,3 x $10^{6}$ org. $\mathrm{m}^{-3}$ entre os quatro tanques estudados, num total de dez espécies. A menor densidade foi observada para Cladocera, variando de $4,7 \times 10^{4}$ a 2,1 x $10^{5}$ org. $\mathrm{m}^{-3}$ num total de seis espécies encontradas, sendo Diaphanosoma birgei a única espécie classificada como muito freqüente. O uso de ração junto com zooplâncton proporcionou melhor rendimento para larvas de B. orbignyanus.
\end{abstract}

Palavras-chave: Brycon orbignyanus, tanques de larvicultura, limnologia, zooplâncton.

\section{Introduction}

A major problem in Brycon orbignyanus production is its high mortality rate during the larvae stage and during development into the fingerling stage. Feeding preference of $B$. orbignyanus larvae consists of crusta-

cean zooplankton, mainly Cladocera and insect larvae. According to Ceccarelli and Senhorini (1996), other fish larvae should be placed together with $B$. orbignyanus larvae in order to avoid cannibalism during the incuba- 
tion period. After this phase B. orbignyanus larvae may be transported to fishponds, although culture success depends on the type and quantity of zooplankton available in the pond, larvae density and water quality.

Lopes et al. (1994) showed that supply of ration + zooplankton to Brycon cephalus Gunther, 1869 established higher survival rates, whereas larvae had high growth rates (length and weight) in zooplankton only treatment. This fact confirmed the importance of live plankton as a basic component for fish initial feed.

Brycon orbignyanus, commonly known as "piracanjuba", is a species of great interest for fish farmers due to its fast growth, food habits (omnivore), easy adaptation to artificial diets, good flesh quality and for its use in sport fishing. "Piracanjuba" is an indigenous species of the river Paraná basin where it used to be found abundantly. However, due to deforestation, pollution and impounding, the species has become rare in its natural habitat (Mendonça, 1996).

Physical, chemical and biological variables regulate the functioning of larvae production tanks. Control of the environment culture conditions is currently considered to be the main factor in production improvement. Actually, the latter depends on management approaches, on water quality monitoring and on knowledge of the species' feeding habits.

Great variability in survival, growth and quality of hatchery-produced fish larvae is a common and complex problem and mass mortalities may occur (Battaglene et al., 2005). In spite of some recent encouraging results involving dispensed diets for fish larvae, the rearing of most freshwater fish species still relies on live food, at least up to metamorphosis. Zooplankton groups, such as Copepoda, Cladocera and Rotifera, are preys widely used in the rearing of fish larvae (Aragão et al., 2004).

Harvested zooplankton has regularly been used as live food for larvae of freshwater fish species. The water quality control in larvae tanks and zooplankton as live food affect variable growth and larval survival (Evjemo et al., 2003).

Given the importance of the water variables conditions and available food in the development and survival of fish larvae, the current research evaluates the effects of two different food treatments (ration + zooplankton and only zooplankton) and water quality in tanks with Brycon orbignyanus larvae

\section{Materials and Methods}

This study was undertaken at the Research Station and Environmental Development of Volta Grande (CEMIG, MG, Brazil), downstream the Volta Grande reservoir, and a water source for CEMIG tanks. Four $8.49 \mathrm{~m}^{2}$ tanks were populated with Brycon orbignyanus larvae, at a density of 94 larvae fish $/ \mathrm{m}^{2}$, and were reared until the $41^{\text {st }}$ day.

The tanks were left empty for 7 days before the experiments and dolomitic lime $\left(\mathrm{MgCO}_{3}\right)$ at $8 \mathrm{~kg} / \mathrm{tank}$ and chicken dung (1000 g.m $\left.{ }^{-2}\right)$ at $9 \mathrm{~kg} /$ tank were added.
Tanks were half filled $(0.23 \mathrm{~m})$ and kept at the same level for 5 days. They were then completed up to $0.45 \mathrm{~m}$ and water was made to flow continuously through the tanks. Larvae were placed in the tanks 2 days after spawning.

B. orbignyanus larvae in the current research originated from the CEMIG breeding stock. Following protocols by Woynarovich and Horvath (1985), recently hatched tambaqui (Colossoma macropomum (Curvier, 1818)) were added to the 36 hatcheries to feed the $B$. orbignyanus larvae and prevent cannibalism. Two types of food treatments were investigated: one containing ration + zooplankton (TR) and another containing only zooplankton (TN). A supplementary diet containing 19\% crude protein was given to larvae in TR up to the $20^{\text {th }}$ day; a pellet-shape ration, containing $20 \%$ crude protein $\left(20 \mathrm{~kg} . \mathrm{d}^{-1}\right)$, was given as from the next day. The experiment was conducted in duplicate $\left(\mathrm{TN}_{1} ; \mathrm{TN}_{2}=\right.$ only zooplankton, and $\mathrm{TR}_{1} ; \mathrm{TR}_{2}=$ ration + zooplankton $)$.

Water samples were analyzed daily, with a $1 \mathrm{~L}$ Van Dorn bottle during the first week and then every four days, in all of the tanks, until the end of experiment. Temperature, conductivity and $\mathrm{pH}$ were determined with Corning temperature meter, Micronal B330 and Metrhon Herisau E 488, respectively. Transparency was determined by Secchi disk, dissolved oxygen, nitrite, nitrate, total phosphorus and orthophosphate were measured according to Golterman et al. (1978). Ammonia, chlorophyll- $a$, alkalinity and inorganic carbon were determined according to Koroleff (1976), Nush (1980) and Mackereth et al. (1978). Residence time was measured by the speed of water entrance into the tanks, assessing time spent for $2 \mathrm{~L}$ water output, expressed in days, needed for the total renewal of water volume in the tanks.

For quantitative and qualitative analysis of zooplankton, samples were obtained with a $58 \mu \mathrm{m}$ mesh plankton net and then preserved in $4 \%$ formalin. Zooplankton organisms were counted in Sedgewick Rafter Cell and examined under 100x magnification. Copepoda nauplii and copepodids of Argyrodiaptomus furcatus Cowgill et al. (1985) and Notodiaptomus iherinig (Wright, 1935); were counted together; density data were expressed in abundance percentage and individuals. $\mathrm{m}^{-3}$. Frequency occurrence was also estimated for total zooplankton organisms, divided into four classes: class 4 (very frequent, from 76 to $100 \%$ ), class 3 (frequent, between 51 and $75 \%$ ), class 2 (moderately frequent, between 26 and $50 \%$ ) and class 1 (low frequency, between 1 and 25\%).

Ten fish larvae were measured for total length with a graded scale and weighed using a $1 \mathrm{~g}$-precision balance. Larvae were measured daily during the first week; later, they were measured at a four-day interval, until the end of the experiment.

Total length and weight of B. orbignyanus larvae were determined by minimum square methods (Santos, 1978). Growth rates compared by method of treatment were analyzed according to Gabriel's procedure (Sokal and Rohlf, 1981), using simultaneous comparisons. Density of zooplankton organisms was evaluated 
by means of the non-parametric Freedman test (Siegel, 1975) and significance level for statistical test results was $\mathrm{p}=0.05$.

\section{Results}

Total transparency of $45 \mathrm{~cm}$ was obtained in tanks with low conductivity, which ranged from 36 to $64 \mu \mathrm{S} . \mathrm{cm}^{-1}$ in $\mathrm{TR}_{1}$, from 28 to $60 \mu \mathrm{S} . \mathrm{cm}^{-1}$ in $\mathrm{TR}_{2}$, from

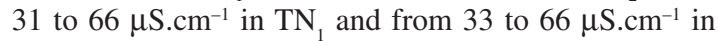
$\mathrm{TN}_{2}$ (Figure 1).

Dissolved oxygen was below $4 \mathrm{mg} . \mathrm{L}^{-1}$ during the period, with the exception of $\mathrm{TN}_{1}$ treatment. A rise in con-
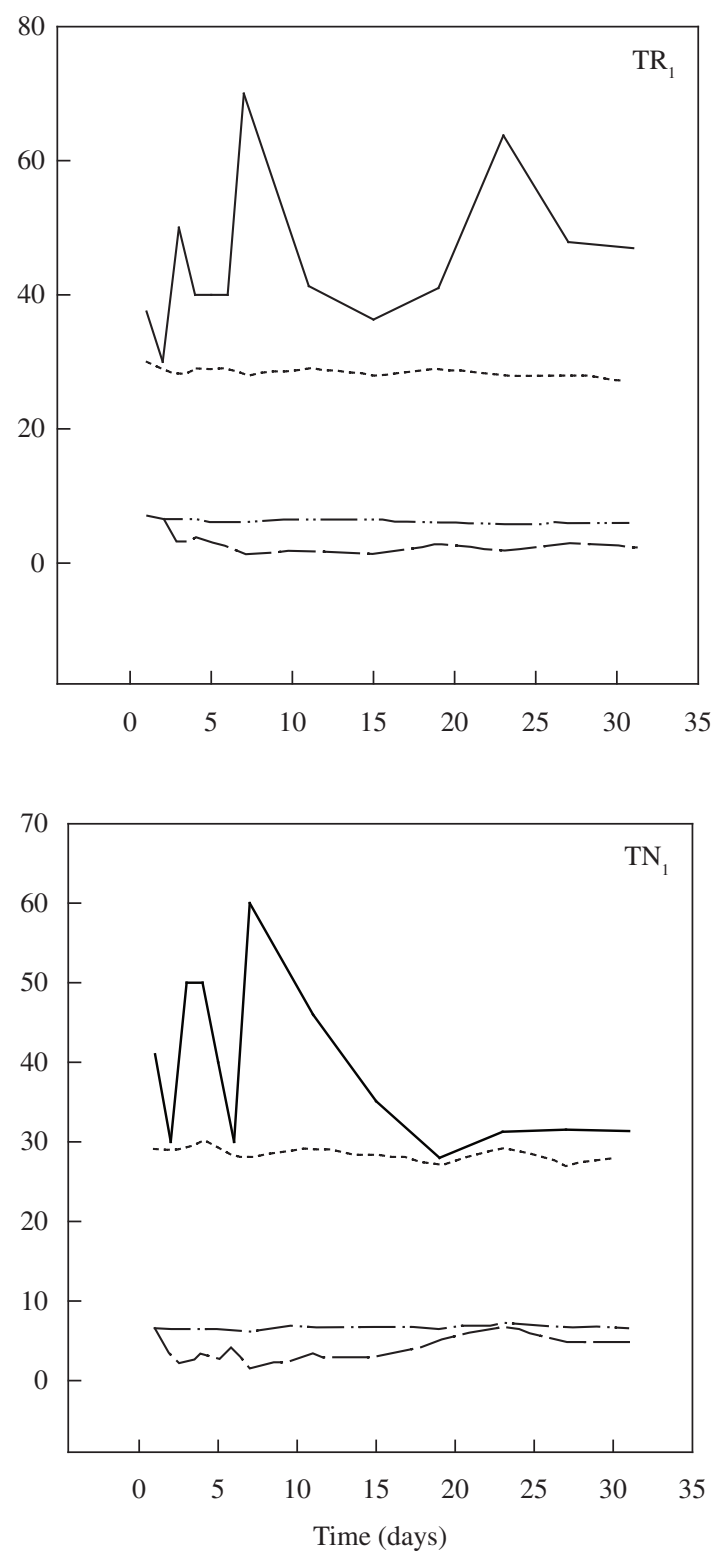

centration above $4.25 \mathrm{mg} . \mathrm{L}^{-1}$ occurred starting from the $11^{\text {th }}$ day, (above $4.25 \mathrm{mg} . \mathrm{L}^{-1}$ ) with its peak at $7.6 \mathrm{mg} . \mathrm{L}^{-1}$ on the $27^{\text {th }}$ day, the highest reported value during the study period (Figure 1).

Water temperature varied from 27 to $30{ }^{\circ} \mathrm{C}$ in the four tanks under analysis. Affected by the oligotrophic conditions of the reservoir, $\mathrm{pH}$ remained acid, with variations between 5.7 and 6.8 in $\mathrm{TR}_{1}$, between 6.1 and 6.6 in $\mathrm{TR}_{2}$, between 6.2 and 6.8 in $\mathrm{TN}_{1}$ and between 6.0 and 6.6 in $\mathrm{TN}_{2}$ (Figure 1).

Free $\mathrm{CO}_{2}$ concentrations in TR and TN treatments were high due to the acidic $\mathrm{pH}$ of the medium and alternated bicarbonate dominance. Alkalinity, with a standard
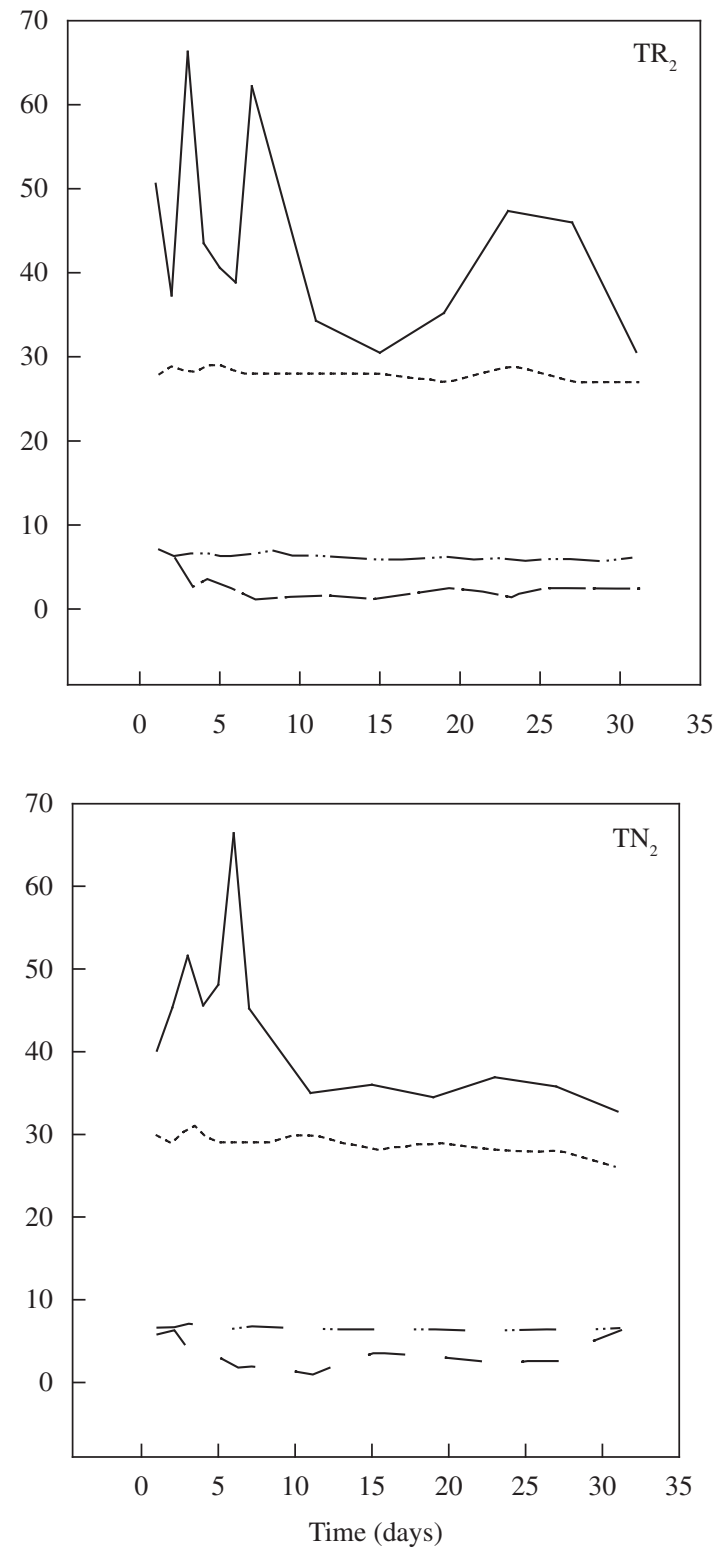

Figure 1. Fluctuation of dissolved oxygen $\left(\mathrm{mg} \cdot \mathrm{L}^{-1},-\longrightarrow\right)$, temperature $\left({ }^{\circ} \mathrm{C}, \ldots.\right), \mathrm{pH}(-.$.$) and conductivity \left(\mu \mathrm{S} . \mathrm{cm}^{-1},-\right)$ of the Brycon orbignyanus larvae tanks, where $\mathrm{TR}=$ ration + zooplankton and $\mathrm{TN}=$ only zooplankton. 
variation similar to bicarbonate with higher concentrations in ration-less treatments, ranged between 11 and $23 \mathrm{mg} . \mathrm{L}^{-1}$ in $\mathrm{TN}_{1}$, and between 15 and $22 \mathrm{mg} . \mathrm{L}^{-1}$ in $\mathrm{TN}_{2}$, when compared to ration treatment with variations from 8 to $27 \mathrm{mg} . \mathrm{L}^{-1}$ and from 6 to $22 \mathrm{mg} . \mathrm{L}^{-1}$ for treatments $\mathrm{TR}_{1}$ and $\mathrm{TR}_{2}$, respectively (Figure 2 ).

Highest ammonium concentrations were reported in the treatment with $\mathrm{TR}_{2}$ ration $\left(740 \mu \mathrm{g} . \mathrm{L}^{-1}\right)$, mainly at the start of the experiment and up to the $9^{\text {th }}$ day; later concentration rates were similar to nitrite and nitrate ones. Throughout the study, nitrogen compounds remained low with the exception of registered sudden ammonium peaks at the start of the experiment (Figure 3).
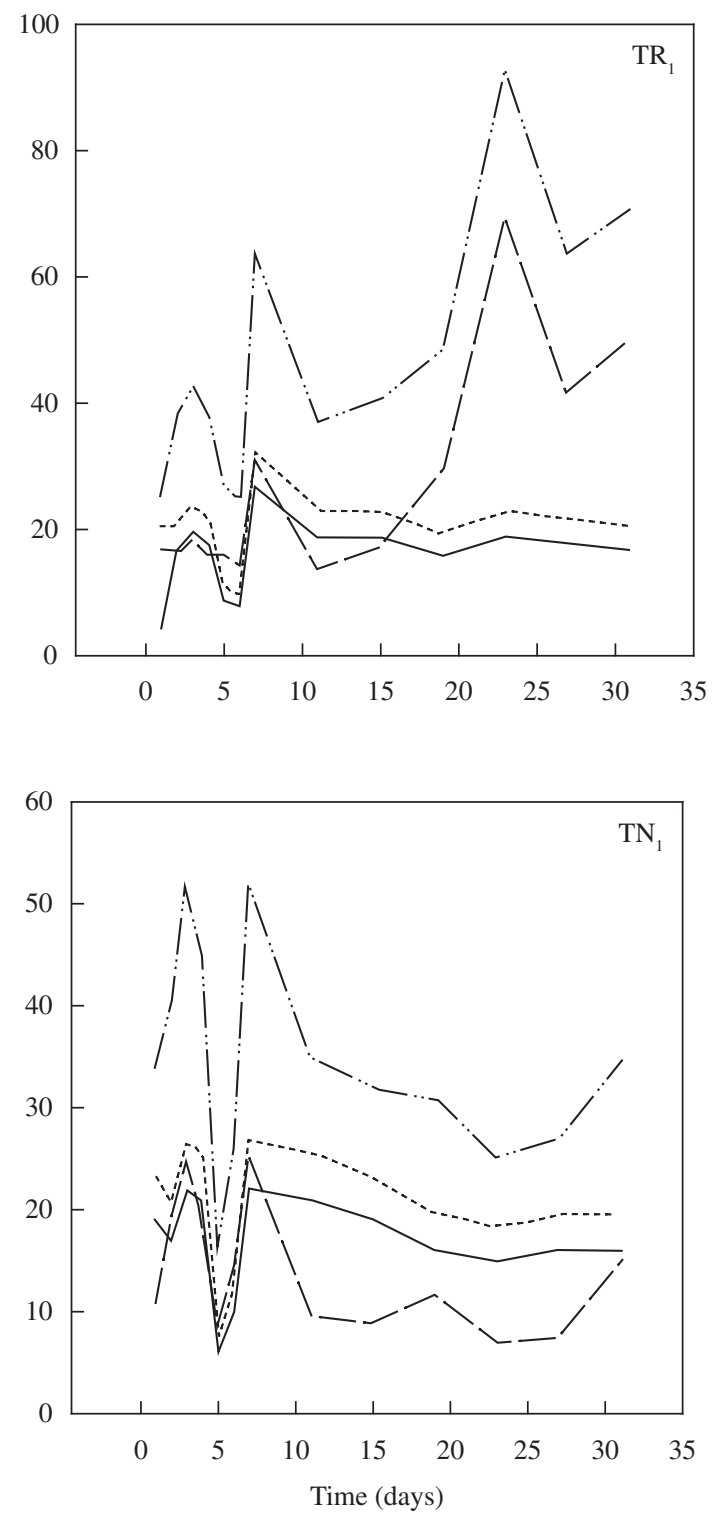

Although high concentrations of total phosphorus and orthophosphate were reported up till the $15^{\text {th }}$ day, rates later on decreased to insignificant concentrations. Phosphorus concentrations in TR treatment were higher and reached a maximum of 847 and $935 \mu \mathrm{g} . \mathrm{L}^{-1}$ in $\mathrm{TR}_{1}$, and $\mathrm{TR}_{2}$ tanks respectively. Chlorophyll- $a$ was lower than $25 \mu \mathrm{g} . \mathrm{L}^{-1}$ during the experimental period (Figure 4).

The zooplankton community consisted of 19 taxa or rather, 10 Rotifera, 6 Cladocera and 3 Copepoda. Table 1 shows their density variations. Although most taxa showed low frequencies (class 1), the short residence time restricted long life span and stimulated the short life-cycle of Rotifera. Actually, the latter constitut-
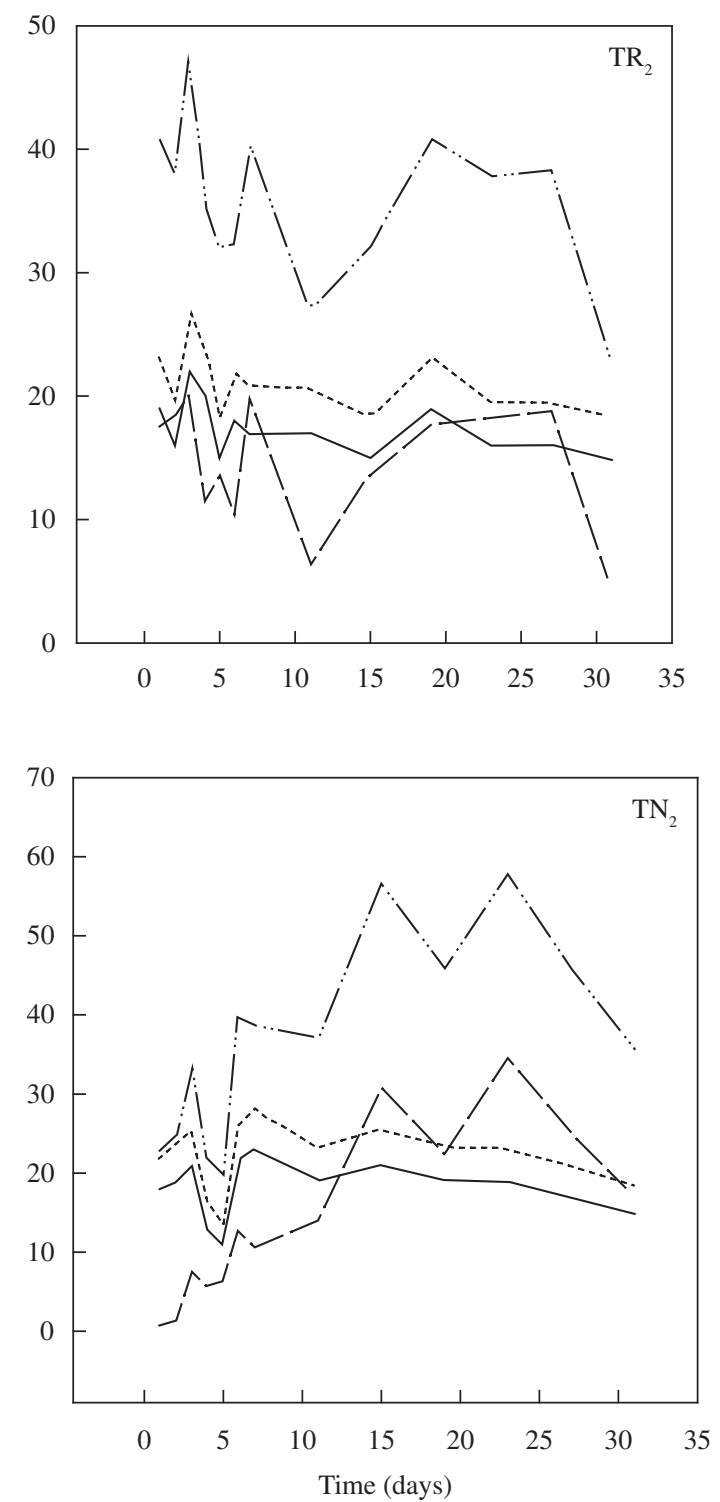

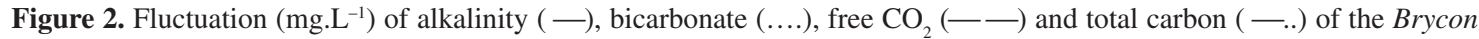
orbignyanus larvae tanks, where: $\mathrm{TR}=$ ration + zooplankton and $\mathrm{TN}=$ only zooplankton. 

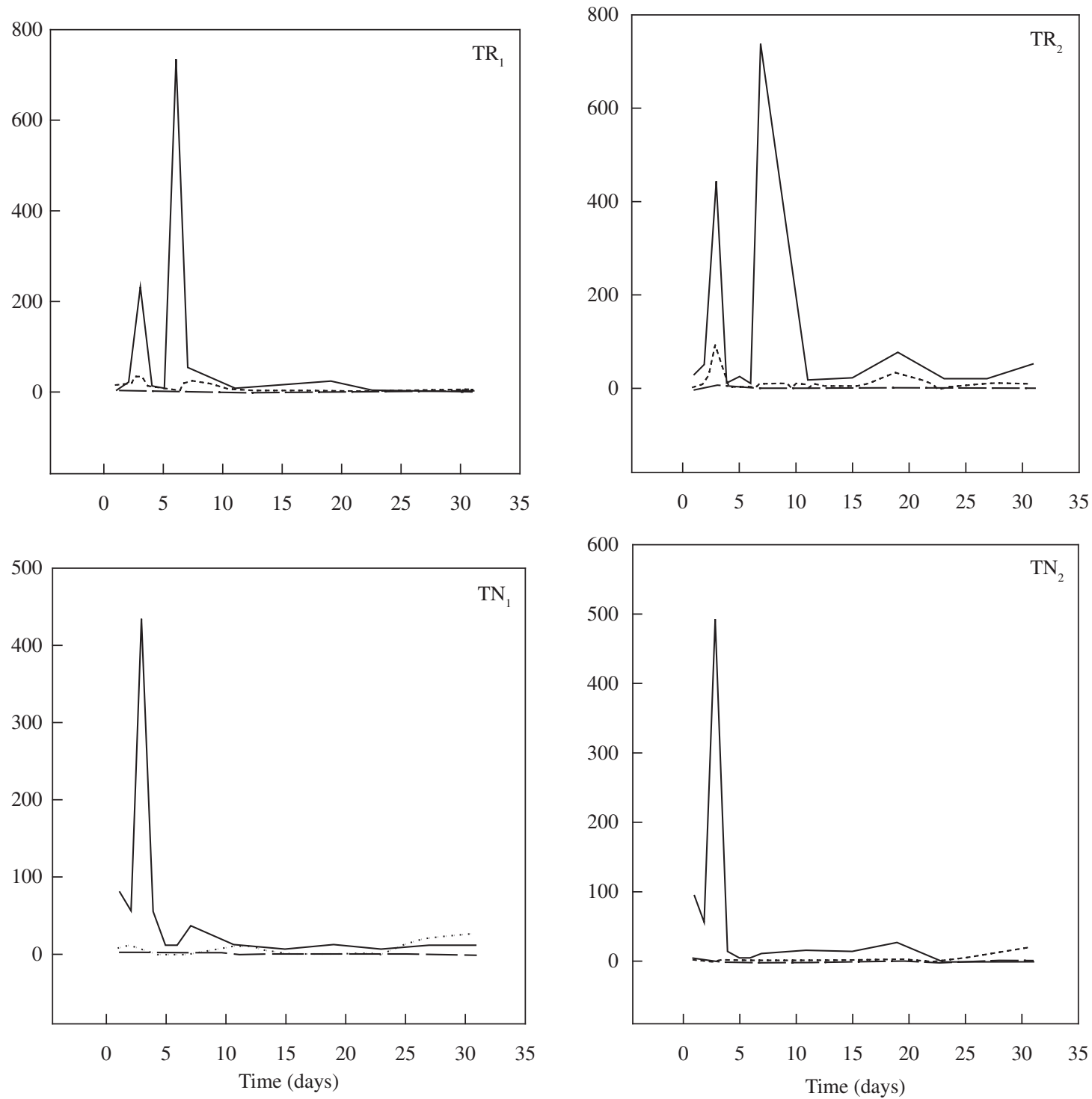

Figure 3. Fluctuation ( $\left.\mu \mathrm{g} \cdot \mathrm{L}^{-1}\right)$ of ammonia $(-)$, nitrite $(--)$ and nitrate (...) of the Brycon orbignyanus larvae tanks, where: $\mathrm{TR}=$ ration + zooplankton and $\mathrm{TN}=$ only zooplankton.

ed the largest number of species and/or genus reported (Table 2).

Rotifera were moderately frequent and were mainly represented by Asplanchna sp., with 1.5 to $3.8 \times 10^{5}$ ind $\mathrm{m}^{-3}$, and by Epiphanes macrourus Barrois and Dady (1894), with 3.5 to $6.0 \times 10^{5}$ ind. $\mathrm{m}^{-3}$. Rotifera dominated the zooplankton community from the $19^{\text {th }}$ day up till the end of the experiment. Copepoda were mostly represented by nauplii and copepodid, with more than 30 and $35 \%$ in TR, and 47 and $45 \%$ in TN. In TR treatment Copepoda - nauplii were considered frequent (class 3 ). Cladocera, the least abundant taxa, were represented mostly by the species Diaphanosoma birgei (Korineck, 1981), with over 54\%. It was the only species classified as class 4 , that is, very frequent, during the study period (Tables 1 and 2, Figure 5). Although all zooplankton spe- cies were, as a rule, reported in treatment TR, Bosmina tubicen Brehm, 1953 and Moina sp. were not reported in TN treatment. The highest number of individuals, was reported in TR 2,010 ind. $\mathrm{m}^{-3}\left(\mathrm{TR}_{1}\right)$ and 2,283 ind. $\mathrm{m}^{-3}$ $\left(\mathrm{TR}_{2}\right)$, was reported in TR (Table 1).

The highest survival rate $(48 \%)$ has been observed for plankton treatment only $\left(\mathrm{TN}_{1}\right)$; however, the percentage was reduced to $20 \%$ for $\mathrm{TN}_{2}$. Survival rates for $\mathrm{TR}_{1}$ and $\mathrm{TR}_{2}$ were 28 and $26 \%$, respectively.

Weight-length relationship was not significantly different $(\mathrm{p}>0.05)$ among the treatments, overlapping between intervals (Table 3 ). The average initial size and weight of the larvae in TR tanks were $1.21 \mathrm{~cm}$ and $0.02 \mathrm{~g}$, respectively, and in TN tanks $1.08 \mathrm{~cm}$ and $0.02 \mathrm{~g}$ in TN tanks. During the experimental period, weights increased more quickly in tanks with ration. In fact, 

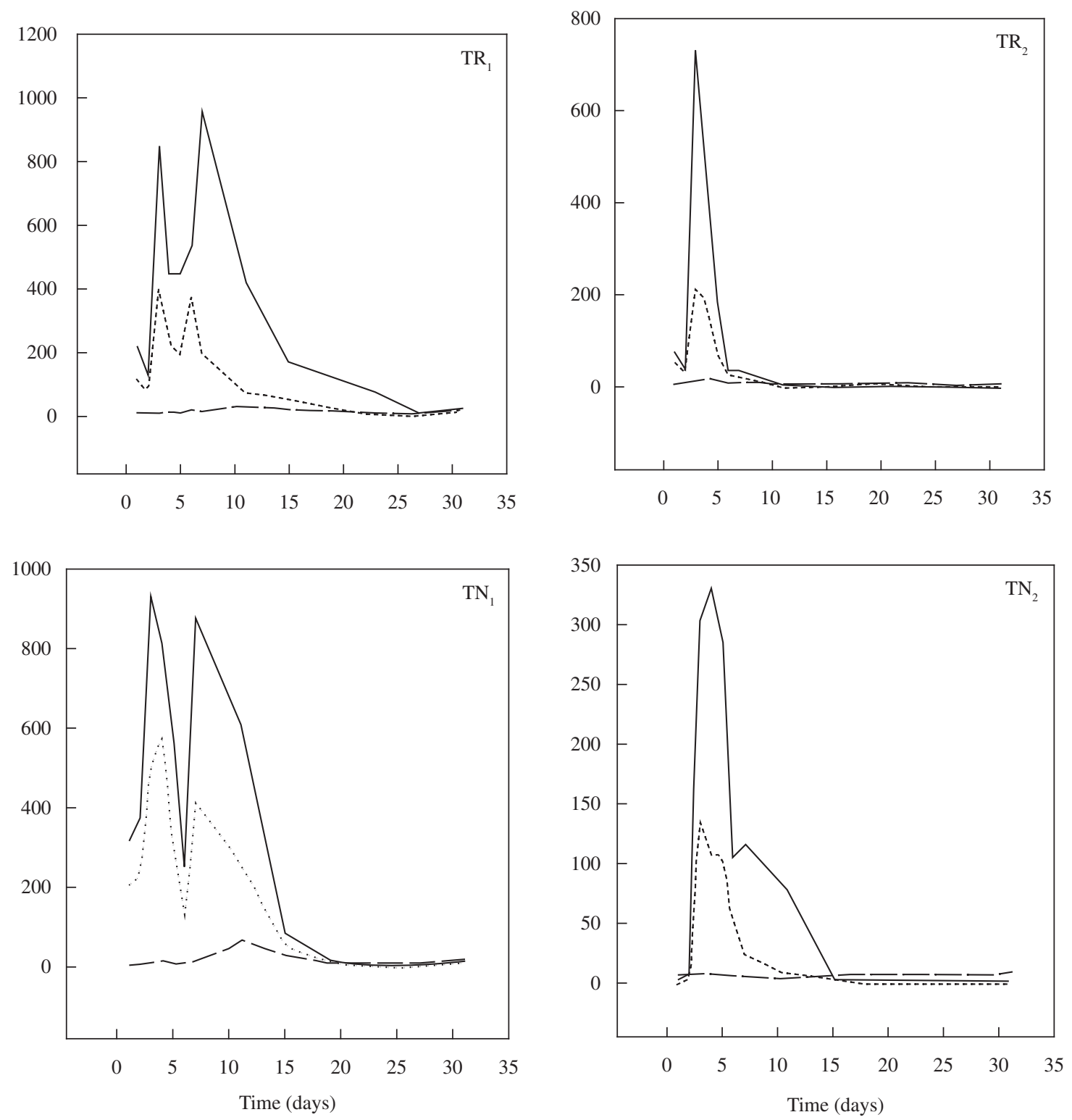

Figure 4. Fluctuation ( $\left.\mu \mathrm{g} \cdot \mathrm{L}^{-1}\right)$ of total phosphorus (-), orthophosphate (...) and chlorophyll- $a$ ( - —) of the Brycon orbignyanus larvae tanks, where: $\mathrm{TR}=$ ration + zooplankton and $\mathrm{TN}=$ only zooplankton.

the larvae reached a final average weight and length of $8.58 \mathrm{~g}$ and $9.06 \mathrm{~g}$, and 8.34 and $8.76 \mathrm{~cm}$ for $\mathrm{TR}_{1}$ and $\mathrm{TR}_{2}$, respectively. Results from ration-less tanks (TN) were lower, final average weights and lengths were 1.43 and $1.72 \mathrm{~g}$ and 4.91 and $5 \mathrm{~cm}$, respectively.

\section{Discussion}

Water temperature in shallow artificial ponds is directly affected by solar radiation. During the experimental period temperature values were within normal limits suitable for the breeding of Brycon orbignyanus. According to Kubtiza (1998), adequate temperature for tropical fish ranges between 20 and $30^{\circ} \mathrm{C}$, with its best between
28 and $32{ }^{\circ} \mathrm{C}$. Total water transparency has been mainly associated with short residence time, continuous flow and shallowness. These factors associated to a water supply from an oligotrophic reservoir, also affected conductivity, which remained below $50 \mu \mathrm{S} . \mathrm{cm}^{-1}$, frequently reported in the Volta Grande reservoir (Rolla et al., 1990).

Acid $\mathrm{pH}$ in tanks affected inorganic carbon compounds with significant rates of free $\mathrm{CO}_{2}$. According to Gomes (1997), acid pH in larviculture tanks negatively affected both the survival and the development of B. cephalus larvae.

Nutrients in water were affected by feed treatment. Due to the feed decomposition and the consequent in- 
Table 1. Total density and composition of zooplankton organisms $\left(\times 10^{3}\right.$ org. $\left.\mathrm{m}^{-3}\right)$ in Brycon orbignyanus larvae tanks, where $\mathrm{TR}=$ ration + zooplankton and $\mathrm{TN}=$ only zooplankton.

\begin{tabular}{|c|c|c|c|c|}
\hline \multirow[t]{2}{*}{ Taxa } & \multicolumn{4}{|c|}{ Density $\left(\times 10^{3}\right.$ ind. $\left.\mathrm{m}^{-3}\right)$} \\
\hline & $\mathbf{T R}_{1}$ & $\mathbf{T R}_{2}$ & $\mathbf{T N}_{1}$ & $\mathbf{T N}_{2}$ \\
\hline \multicolumn{5}{|l|}{ ROTIFERA } \\
\hline Asplanchna sp & 376 & 306 & 152 & 158 \\
\hline Brachionus dolabratus & 92 & 36 & 32 & 35 \\
\hline Brachionus falcatus & 42 & 95 & 36 & 28 \\
\hline Epiphanes macrourus & 603 & 552 & 464 & 350 \\
\hline Filinia longiseta & 12 & 12 & 40 & 26 \\
\hline Keratella americana & 29 & 31 & 38 & 43 \\
\hline Lecane sp & 10 & 5 & 28 & 66 \\
\hline Lecane pertica & 28 & 48 & 32 & 29 \\
\hline Ptygura sp & 75 & 46 & 92 & 75 \\
\hline Trichocerca sp & 95 & 150 & 58 & 58 \\
\hline \multicolumn{5}{|l|}{ CLADOCERA } \\
\hline Bosmina tubicen & 4 & 2 & 3 & - \\
\hline Ceriodaphnia sp & 8 & 5 & 5 & 5 \\
\hline Ceriodaphnia cornuta & 10 & 10 & 4 & 4 \\
\hline Daphnia gessneri & 2 & 3 & 2 & 2 \\
\hline Diaphanosoma birgei & 29 & 171 & 33 & 191 \\
\hline Moina $\mathrm{sp}$ & 5 & 2 & - & 4 \\
\hline \multicolumn{5}{|l|}{ COPEPODA } \\
\hline Thermocyclops decipiens adult & 63 & 47 & 86 & 48 \\
\hline Notodiaptomus iheringi adult & 49 & 172 & 134 & 360 \\
\hline Argyrodiaptomus furcatus adult & 26 & 187 & 120 & 66 \\
\hline *Copepodid & 69 & 240 & 82 & 65 \\
\hline *nauplii & 383 & 163 & 490 & 334 \\
\hline
\end{tabular}

- not observed in the sample.

*A. furcatus and $N$. iheringi copepodid and nauplii.

corporation of these elements into the water column by algal biomass, the concentration of nutrients in TR tanks was higher. Since movement stirred by water input and output in tanks causes more active nitrification, lower nitrite concentrations were reported when the latter were compared to nitrate and ammonia concentration rates.

Sipaúba-Tavares et al. (2000) also reported low nitrite and high nitrate concentrations in tilapia tanks with water renewal. This fact demonstrated not only absorption of the element by phytoplankton but also activities of nitrifying bacteria in fishponds.

Since higher concentrations of orthophosphate and total phosphorus occurred in TR treatments, the direct effect of inert feed on the dynamics of nutrients has been indicated. Avnimelech (1998) verified that in earthen carp ponds $20 \%$ of phosphorus and $25 \%$ of nitrogen were recovered when fish were harvested. The remaining percentage was accumulated in sediments or became available in the water column.

Water mass circulation was also affected by nutrient availability, which in turn was influenced by the continuous water flow and by the management of fish harvesting, which triggered the re-suspension of the sediment. Furthermore, phosphorus compounds of food affect its availability in the environment: greater loss occurs when food has a low conversion. Whereas nitrogen depends on several factors, fish excretion rates depend on the food rate, digestibility and availability (Pillary, 1992).

Low chlorophyll- $a$ concentration may be associated with the water short residence time which will have restricted a long permanence of phytoplankton biomass in the ponds. This fact influenced the low dissolved oxygen concentrations due to the fact that oxygen consumption and phytoplankton production were more important than diffusion processes. According to Gomes et al. (2000), Brycon can survive in water with low levels of dissolved oxygen.

Short residence time in ponds affected directly the zooplankton community, characterized by low species diversity. However, short life-span organisms, such as Rotifera, were ecologically better adapted to unforeseen changes of the environment and, in the long run, become dominant. Probably associated with higher availability of nutrients in culture tanks, Rotifera represented more 
Table 2. Specific composition and frequency of different zooplankton taxa in Brycon orbignyanus larvae tanks with two treatments: ration + zooplankton (TR) and only zooplankton (TN), where: $1=1$ to $25 \%$ frequency; $2=26$ to $50 \%$ frequency; $3=$ 51 to $75 \%$ frequency and $4=76$ to $100 \%$ frequency.

\begin{tabular}{|c|c|c|c|c|}
\hline \multirow[t]{2}{*}{ Taxa } & \multicolumn{4}{|c|}{ Frequence } \\
\hline & $\mathbf{T R}_{1}$ & $\mathbf{T R}_{2}$ & $\mathbf{T N}_{1}$ & $\mathbf{T N}_{2}$ \\
\hline \multicolumn{5}{|l|}{ ROTIFERA } \\
\hline Lecane sp & 1 & 1 & 1 & 1 \\
\hline Brachionus dolabratus & 1 & 1 & 1 & 1 \\
\hline Filinia longiseta & 1 & 1 & 1 & 1 \\
\hline Brachionus falcatus & 1 & 1 & 1 & 1 \\
\hline Lecane pertica & 1 & 1 & 1 & 1 \\
\hline Keratella americana & 1 & 1 & 1 & 1 \\
\hline Ptygura sp & 1 & 1 & 1 & 1 \\
\hline Trichocerca $\mathrm{sp}$ & 1 & 1 & 1 & 1 \\
\hline Asplanchna sp & 2 & 1 & 2 & 2 \\
\hline Epiphanes macrourus & 2 & 2 & 2 & 2 \\
\hline \multicolumn{5}{|l|}{ CLADOCERA } \\
\hline Daphnia gessneri & 1 & 1 & 1 & 1 \\
\hline Moina sp & 1 & - & 1 & 1 \\
\hline Bosmina tubicen & 1 & 1 & 1 & 1 \\
\hline Ceriodaphnia cornuta & 1 & 1 & 1 & 1 \\
\hline Ceriodaphnia sp & 1 & 1 & 1 & 1 \\
\hline Diaphanosoma birgei & 3 & 3 & 4 & 4 \\
\hline \multicolumn{5}{|l|}{ COPEPODA } \\
\hline Thermocyclops decipiens adult & 1 & 1 & 1 & 1 \\
\hline Notodiaptomus iheringi adult & 1 & 1 & 1 & 2 \\
\hline Argyrodiaptomus furcatus adult & 1 & 1 & 2 & 1 \\
\hline *copepodid & 1 & 1 & 2 & 1 \\
\hline *nauplii & 3 & 3 & 1 & 2 \\
\hline
\end{tabular}

*A. furcatus and N. iheringi copepodid and nauplii.

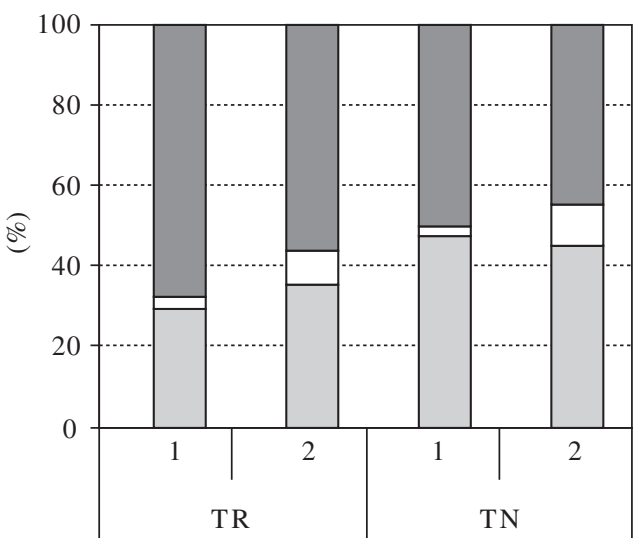

$\square$ Rotifera $\quad \square$ Cladocera $\square$ Copepoda

Figure 5. Relative (\%) composition of zooplanktonic community found in the ponds for the two tanks, where: TR = ration + zooplankton and $\mathrm{TN}=$ only zooplankton. than $50 \%$ of the organisms found in the experiment and were more abundant in TR treatment. High Rotifera density has been associated with the capacity of organisms to adapt themselves quickly to environmental disruption and perturbation. In fact, prevalence in physically unstable systems, such as fishponds, has been the trend (Sipaúba-Tavares and Colus, 1997).

According to Sendacz and Kubo (1982), CalanoidaCopepoda is more abundant than Cladocera in oligotrophic waters, a characteristic of the water supplied to the tanks. Lower abundance of Cladocera in tanks may be associated with predation by $B$. orbygnianus larvae, which prefer zooplankton crustaceans, mainly Cladocera (Ceccarelli and Senhorini, 1996). In their study on survival, growth and trophic dynamics in "piracanjuba" larvae tanks, Senhorini and Fransozo (1998) verified that Cladocera were preferentially ingested by the larvae

Coupled to predation, high water transparency, low temperatures and water flow are unfavorable factors to Cladocera in fish tanks (Sipaúba-Tavares and Colus, 1997). Cladocera were more abundant only at the start of the experimental period when water temperature was 
Table 3. Data on the relationship weight / length of Brycon orbignyanus in two different treatments $(\mathrm{TR}=$ ration + zooplankton and $\mathrm{TN}=$ only zooplankton), where $\mathrm{N}=$ number of specimens; $\mathrm{a}=$ numerical value of interceptor in the allometric equation; $\mathrm{b}=$ angular coefficient rate with confidence interval, $\mathrm{r}=$ correlation coefficient rate.

\begin{tabular}{cllll}
\hline Weight/length relationship & \multicolumn{1}{c}{$\mathbf{T R}_{\mathbf{1}}$} & \multicolumn{1}{c}{$\mathbf{T R}_{\mathbf{2}}$} & \multicolumn{1}{c}{$\mathbf{T N}_{\mathbf{1}}$} & \multicolumn{1}{c}{$\mathbf{T N}_{\mathbf{2}}$} \\
\hline $\mathrm{N}$ & 105 & 132 & 107 & 137 \\
$\mathrm{~A}$ & 0.0100 & 0.0095 & 0.0096 & 0.0086 \\
$\mathrm{~B}$ & $3.13 \pm 0.25$ & $3.07 \pm 0.22$ & $3.11 \pm 0.26$ & $3.18 \pm 0.24$ \\
$\mathrm{R}$ & 0.998 & 0.981 & 0.997 & 0.994 \\
\hline
\end{tabular}

high. Although Diaphanosoma birgei was the only dominant one among Cladocera, it was also the only zooplankton species classified as frequent in the tanks.

According to Pereira et al. (2004), predominance of Diaphanosoma birgei in fish tanks is associated with continuous water flow, low dissolved oxygen and high phosphorus rates. High phosphorus rates in $\mathrm{TR}_{2}$ affected the high species density observed, since it represented $88.6 \%$ of all Cladocera reported.

The water supply of the culture tanks came from an oligotrophic reservoir and directly affected the Copepoda community. In fact, the two Diaptomidae species, Notodiaptomus iheringi and Argyrodiaptomus furcatus, were the most abundant. Thermocyclops decipiens, characteristic of mesotrophic and eutrophic environments (Sendacz and Kubo, 1982), represented a single occurrence of a Cyclopoida species.

Zooplankton fluctuations are triggered by several factors such as temperature, light and dark periods, water quality, food availability, competition and predation. In fish hatcheries, management may also modify the reproductive cycles of these organisms and population succession (Sipaúba-Tavares and Colus, 1997).

Survival rates were low. Whereas only in treatment $\mathrm{TN}_{1}$ a $48 \%$ survival occurred, survival rates were lower than $28 \%$ in the other tanks. Lopes et al. (1994) demonstrated that supply of zooplankton plus ration caused higher survival rates for Brycon cephalus.

According to Battaglene et al. (2005), Rotifera were a likely source of bacterial load to larval striped trumpeter (Latris lineata) in tanks. Moreover, Evjemo et al. (2003) verified that total protein in Calanoida-Copepoda was higher than $50 \%$ of dry weight than that of Rotifera. In the current experiment, Rotifera reached high densities and Copepoda, low densities. These factors may be influenced by growth and survival results of Brycon orbignyanus larvae. Quantity and quality of available food and the control of the culture water variations directly affected the survival and performance of fish larvae.

Since there was no difference between growth rates within the weight-length relationship, condition factors of larvae in the treatments were similar $(p>0.05)$. Condition factors showed the fish well-being within a certain environment and were associated with conditions in the allometric equation $\mathrm{y}=\mathrm{ax}^{\mathrm{b}}$, adjusted to weight and length data (Braga, 1997).
Pronounced fluctuation of organisms in Rotiferadominant tanks has been reported, followed by Copepoda and Cladocera. Fluctuation in shallow artificial fish culture systems are probably associated with water flow, quantity of available food, chemical and physical changes of water and biological interactions including predation and competition. Zooplankton was thus affected by short life-span water residence which favored opportunist species, such as Rotifera, and affected the survival of B. orbignyanus larvae in tanks.

Results indicate some management recommendations can be applied in the larvae culture station of Volta Grande (CEMIG) so that the survival of B. orbignyanus larvae may be increased:

1) Water flow decrease in tanks in order to retain phytoplankton biomass and consequently to increase the quantity and quality of zooplankton organisms; water turbidity caused by planktonic organisms increases, light penetration is reduced and dissolved oxygen in the tanks is increased.

2) Since the ration + zooplankton treatment (TR) showed better results, this treatment should be recommended for Brycon orbignyanus larvae.

3) Deeper ponds may be used, since these systems are directly affected by local climate.

4) In this study, water in the tanks was supplied by an oligotrophic reservoir characterized by low plankton densities; consequently, tank construction with the sole aim to cultivate zooplankton as a food reserve for $B$. orbignyanus larvae is recommended.

Acknowledgments - The authors would like to thank the Brazilian Council for Scientific and Technological Development (CNPq) for its support with a scholarship to E.J. da S. Alvarez, and the Research Station and Environmental Development of Volta Grande (CEMIG) for its logistical support to this experiment.

\section{References}

ARAGÃO, C., CONCEIÇÃO, LEC., DINIS, MT. and FYHN, NJ., 2004. Amino acid pools of rotifers and Artemia under different conditions: nutritional implications for fish larvae. Aquaculture, vol. 234, no. 33, p. 429-445.

AVNIMELECH, Y., 1998. Minimal discharge from intensive fishponds. World Aquaculture, march, vol. 29, no. 1, p. 32-37. 
BATTAGLENE, SC., MOREHEAD, DT., COBCROFT, JM., NICHOLS, PD., BROWN, MR. and CARSON, J., 2006. Combined effects of feeding enriched rotifers and antibiotic addition on performance of striped trumpeter (Latris lineata) larvae. Aquaculture, vol. 251, no. 2-4, p. 456-471.

BRAGA, FM. de S., 1997. Análise da equação alométrica na relação peso e comprimento e o fator de condição em Plagioscion aquamosissimus (Teleostei, Sciaenidae). Rev. Brasil. Biol., vol. 57, no. 3, p. 417-425.

CECCARELLI, PS. and SENHORINI, J., 1996. Brycon viabilização da produção de alevinos. Panorama Aquicultura, vol. 6 , no. 35 , p. 10-11.

EVJEMO, JO., REITAN, KI. and OLSEN, Y., 2003. Copepods as live food organisms in the larval rearing of halibut larvae (Hippoglossus hippoglossus) with special emphasis on the nutritional value. Aquaculture, vol. 227, no. 1-4, p. 191-210.

GOLTERMAN, HL., CLYMO, RS. and OHNSTAD, MAM., 1978. Methods for physical and chemical analysis of fresh water. London, Blackwell Scientific Publication. 213 p.

GOMES, LC., 1997. Influência da densidade de estocagem na sobrevivência, crescimento e produtividade de larvas de matrinxã Brycon cephalus, GÜNTHER, 1869 (Pisces, Characidae) em tanques. (Dissertação Mestrado) - UFSM, Santa Maria, RS, 110 p.

GOMES, LC., BALDISSEROTTO, B. and SENHORINE, JA., 2000. Effect of stocking density on water quality, survival, and growth of larvae of the matrinxã, Brycon cephalus (Characidae), in ponds. Aquaculture, vol. 183, no. 1-2, p. 73-81.

KOROLEFF, F., 1976. Determination of nutrients. In GRASHOF, E. and KREMLING, E. (eds.). Methods of sea water analysis. Verlag Chemie Wenhein, New York. p. 117-181.

KUBITZA, F., 1998. Qualidade da água na produção de peixes. ESALQ/USP, Jundiaí, SP. 60 p.

LOPES, RNM., SENHORINI, JA. and SOARES, MCF., 1994. Crescimento e sobrevivência de larvas de matrinxã Brycon cephalus Günther, 1869, (PISCES, CHARACIDAE) sob diferentes dietas alimentares. Bol. Téc. CEPTA 7, no. único, p. $41-48$.

MACKERETH, FJH., HERON, J. and TALLING, JF., 1978. Water analysis: some revision methods for limnologists. Freshwater Biological Association. Scientific Publication 36, Amblesie, Titus Wilson \& Sons Ltda. 121 p.
MENDONÇA, JOJ., 1996. O genêro Brycon: piracanjuba, matrinchã, piraputanga e piabanha, entre outros. Panorama Aquicultura, vol. 6, no. 33, p. 14-15.

NUSH, EA., 1980. Comparison of different methods for chlorophyll and phaeopigments determination. Arch. Hydrobiol, vol. 14, p. 14-36.

PEREIRA, RHG., ESPÍNDOLA, ELG. and ELER, MN., 2004. Limnological variables and their correlation with water flow in fishponds. Acta Limnol. Bras., vol. 16, no. 3, p. 263-271.

PILLARY, TVR., 1992. Aquaculture and environment. Oxford, Fish News Books, Blackwell Science Ltda, 189 p.

ROLLA, ME., DABÉS, MBGS., FRANÇA, RC. and FERREIRA, EMVM., 1990. Aspectos limnológicos do reservatório de Volta Grande, Minas Gerais/São Paulo. Acta Limnologica Brasiliensia, vol. 3, no. 1, p. 219-244.

SANTOS, EP., 1978. Dinâmica de populações aplicada à pesca e piscicultura. São Paulo: HUCITEC Ltda, Editora da Universidade de São Paulo. 129 p.

SENDACZ, S. and KUBO, E., 1982. Copepoda (Calanoida e Cyclopoida) de Reservatórios do Estado de São Paulo. B. Inst. Pesca, vol. 9, no. 1, p. 51-89.

SENHORINI, JA. and FRANSOZO, A., 1998. Sobrevivência e crescimento de larvas de "piracanjuba", (Brycon orbignyanus) e a dinâmica trófica em viveiros de larvicultura. In Simpósio Brasileiro de Aqüicultura, Recife, p. 257.

SIEGEL, S., 1975. Estatística não-paramétrica. Ed. Mcgraw-Hill do Brasil. São Paulo, 350 p.

SIPAÚBA-TAVARES, LH. and COLUS, DS. DE O., 1997. Estrutura da comunidade fitoplanctônica e zooplanctônica em dois viveiros de cultivo semi-intensivo de peixes (Jaboticabal, SP., Brasil). Bol.Lab. Hidrobiol., vol. 10, no. único, p. 51-64.

SIPAÚBA-TAVARES, LH., YOSHIDA, C. and BRAGA, FM. DE S., 2000. Effects of continuous water exchange on the limnology of Tilapia (Oreochromis niloticus) culture tanks. Proceedings from Fifth International Symposium on Tilapia Aquaculture, RJ, Brazil, p. 279-287.

SOKAL, RR. and ROHLF, FJ., 1981. Biometry: The principles and practice of statistics in biological research. W.H. Freeman and Company San Francisco. 85 p.

WOYNAROVICK, E. and HORVATH, L., 1985. A propagação artificial de peixes de águas tropicais: Manual de extensão. FAO/CODEVASF/CNPq, Brasília, 220 p. 